\title{
Sacral Topography of the Tver Kremlin in the Period of Appanage Principalities
}

\author{
Aleksey Salimov ${ }^{1, *}$ Vasily Danilov ${ }^{2, a}$ Elena Romanova ${ }^{3, a}$
}

\begin{abstract}
${ }^{1}$ Scientific-Research Institute of Theory and History of Architecture and Urban Planning, Branch of the Central Institute for Research and Design of the Ministry of Construction and Housing and Communal Services of the Russian Federation (NIITIAG), Tver, Russia

${ }^{2}$ The Russian State University named after A.N. Kosygin, Tver, Russia

${ }^{3}$ Tver State United Miseum, Tver, Russia

${ }^{\mathrm{a}} \mathrm{E}-\mathrm{mail}$ : romartver@mail.ru

${ }^{*}$ Corresponding author.E-mail: sampochta@mail.ru
\end{abstract}

\begin{abstract}
The following article shows the development of church building in the Tver Kremlin in the 13th -15 th centuries. The authors localize and describe all known wooden and stone temples using the written and archaeological sources of the period. The authors state that some decades after the establishment of the Tver Principality, by the end of the 13th century numerous temples had been built in the Tver Kremlin. By that time, the only stone construction was the Cathedral of Transfiguration. The 14th century did not substantially change the correlation between the stone and wooden constructions either, though two stone aisles to the cathedral were erected.
\end{abstract}

Keywords: The Tver Kremlin, wooden church, stone temple

\section{INTRODUCTION}

In our opinion, sacred topography in the strict sense principally means research and description of the places connected with the Bible and the New Testament history.

As applied to medieval Russian cities and even wider territories, the subject of the sacred topography is somewhat different: defining the location of churches in concrete populated places, defining their consecration and, finally, detecting a trend in consecration as well as the location of churches and monasteries. One of the tasks is to reveal the programmes for building temples of the defined consecration for political gain or the absence of such plans.

Besides that, churches and monasteries have particular significance in the topographical space of a city as centres of spiritual, cultural and political activities. Chronicle corpuses, book copies, masterpieces of icon painting and jewellery were made there. This is why the research of church topography of a city and revealing spiritual and/or political programmes of the power behind the practice of constructing and consecrating temples and abbeys is essential. Our paper is given over to the results of the

*Fund: The research has been done with the financial support of the RFBR according to the project 19-012-00025. studies of the sacred topography of the Tver Kremlin in the period of the Principality independence.

\section{THE SACRED TOPOGRAPHY OF THE TVER KREMLIN IN THE 13TH - 15TH CENTURIES}

Though in recent years several works containing the analysis of the cathedral complex, localization and reconstruction of the Bishop's Yard and the Princes' Yard have been published and the main nodes of the Kremlin planning structure have been defined [1] [2] [3], the problem still has not been sufficiently studied. Of particular note is the research on the Bishop's Yard ensemble due to its historiography part containing the analysis of numerous literature resources on the topography of the Tver Kremlin [1]. However, researchers paid little attention to the localization of several churches built in the Kremlin between the 13th and 17 th centuries. Primarily it can be explained by a scarcity of documental sources for that period and a lack of archaeological data. The information currently gathered let us define, though tentatively, the possible location of some churches, which were probably made of wood at the time of their first mention in the sources.

The earliest written evidence about a church located in the Tver Kremlin refers to 1271, when the first prince of Tver died and was buried in the Church of Kozma and Demjan [4]. At that time, not only could it be the main temple of the city but also a cathedral of the 
Tver eparchy, which was established in 1260 s by Yaroslav Yaroslavich [5], [6].

The location of the Church of Kozma and Demjan was traditionally connected with the place where the stone Cathedral of Our Saviour Transfiguration stood until 1935. It succeeded the Kozma and Demjan temple, evidently a wooden building.

During archaeological excavations of 2012-2014 carried out at the location of the Saviour Transfiguration Cathedral of 1689-1696 (which was demolished in 1935), a place without burials was found in the territory of the nearby necropolis. The authors consider it to be the location of the Kozma and Demjan Church [7]. Taking into account the chronology of the excavated burials, this conclusion seems to be right, but contrary to the opinion of the researches who excavated the place, the stone Cathedral of Our Saviour Transfiguration of 1286-1290 was not found there [3]. However, even the documentary evidence does not deny the possibility of correlating the part of necropolis free from burials with the locality of the Kozma and Demjan Church. In fact, the information in Lavrentyevskaya Chronicle about breaking ground for the stone Kozma and Demjan Church in 1285, which in the process of constructing was reconsecrated in the name of Our Saviour Transfiguration, can be considered simply as a fact of breaking ground for a stone church of the same consecration near the wooden temple which it was to replace. Evidently, the reconsecration took place rather early, because the small consecration of the unfinished stone temple was performed, as was in the case of the Cathedral of Our Savior Transfiguration in 1287 [9].

The fact of creating in 1285-1290 the stone Cathedral of Our Saviour Transfiguration but not the Kozmodamjansky one allows to suggest that after consecrating the stone Cathedral of Our Saviour Transfiguration, the wooden Church of Kozma and Demjan could stay as a part of the cathedral complex, though for a short time.

We cannot state that the Church of Kozma and Demjan had been a construction of a venerable ancientness by 1285 , for it is known that during a large fire of 1276 , "the city of Tver was totally burnt down, but one church remained" [4]. That could be another church, not of Kozma and Demjan.

To the exclusion of the locality of the Cathedral of Our Saviour Transfiguration at the site of the excavations of 2012-2014, we can suggest two places for the localization of that temple, most promising in our opinion, taking into account some archaeological evidence. These can be the grounds southeast or northeast of the place where the new Cathedral of Our Saviour Transfiguration was built in 1689-1696 ("Fig. 1", "Fig. 2").
In the late 13th century, another church could be created in the bell-tower constructed near the cathedral. Some documents allow us to make this conclusion. It is known, for example, that beside "the old" bell-tower of the cathedral, a new one was erected in 1407 [10] in a place where the Church of John mentioned in the Dozornaya (Checking) book of the middle of the 16th century, was apparently located [11]. In its turn, the Cadastre book of 1677-1628 specified it as the Church of John the Baptist [12]. An additional, though indirect, argument for this name of the church in the cathedral bell-tower since its creation is the fact that the pillarshaped church "for the bells" (a bell tower) erected in 1329 near the Cathedral of the Assumption in the Moscow Kremlin was also named John (John Climacus) [2] ("Fig. 1", "Fig. 2").

We do not know what material the cathedral belltower in the Tver Kremlin was made of in the late 13th century, but in 1407 it was probably made of stone. The uncertainty of the locality of the first Cathedral of Our Saviour Transfiguration makes us suggest some variants for the place of its bell-tower as well ("Fig. 1", "Fig. 2").

The same circumstance determines the presence of two variants of the locality of another construction of the late 13th century - the Church of St. Athanasius ("Fig. 1", "Fig. 2"). In 1297, however, when the erection of that church was mentioned in a chronicle, it was probably renewed after the fire of 1295 during which "the city of Tver was totally burnt down" [4]. In the late 14th century, this church was a Cathedral of the St. Athanasius Monastery where in 1399, the Tver Prince Mikhail Aleksandrovich took the monastic vows before his death [13].

The cadastre books of the middle of the 16th century help to define the locality of the St. Athanasius Monastery, which was mentioned there as placed "behind the altar of the Transfiguration Cathedral" [11] The wooden Church of St. Athanasius the Great was burnt down during the Discord of the early 17 th century [14]. It was renewed between 1616 and 1626, so it was mentioned as "the Temple of St. Athanasius and Cyril, wooden, low" [15]. The Cathedral of St. Athanasius Monastery had become "rather dilapidated" by the end of the 17th century [16]. It was evidently demolished shortly after the cadastre of the early 18th century, as it was absent from the city map of 1710s [17].

The appearance of the Cathedral of the St. Athanasius Monastery on the chronic pages in the late 13th century and its localization behind the altar of the Cathedral of Transfiguration in the late 14th century give grounds to suggest (following N.N. Voronin) that the erection of that temple should be connected with an order of the first Tver Prince Yaroslav Yaroslavich, for he had a monastic name Athanasius [18]. Therefore, together with the Church of Kozma and Demjan, the 
Cathedral of the St. Athanasius Monastery could be considered the earliest temple of the medieval Tver.

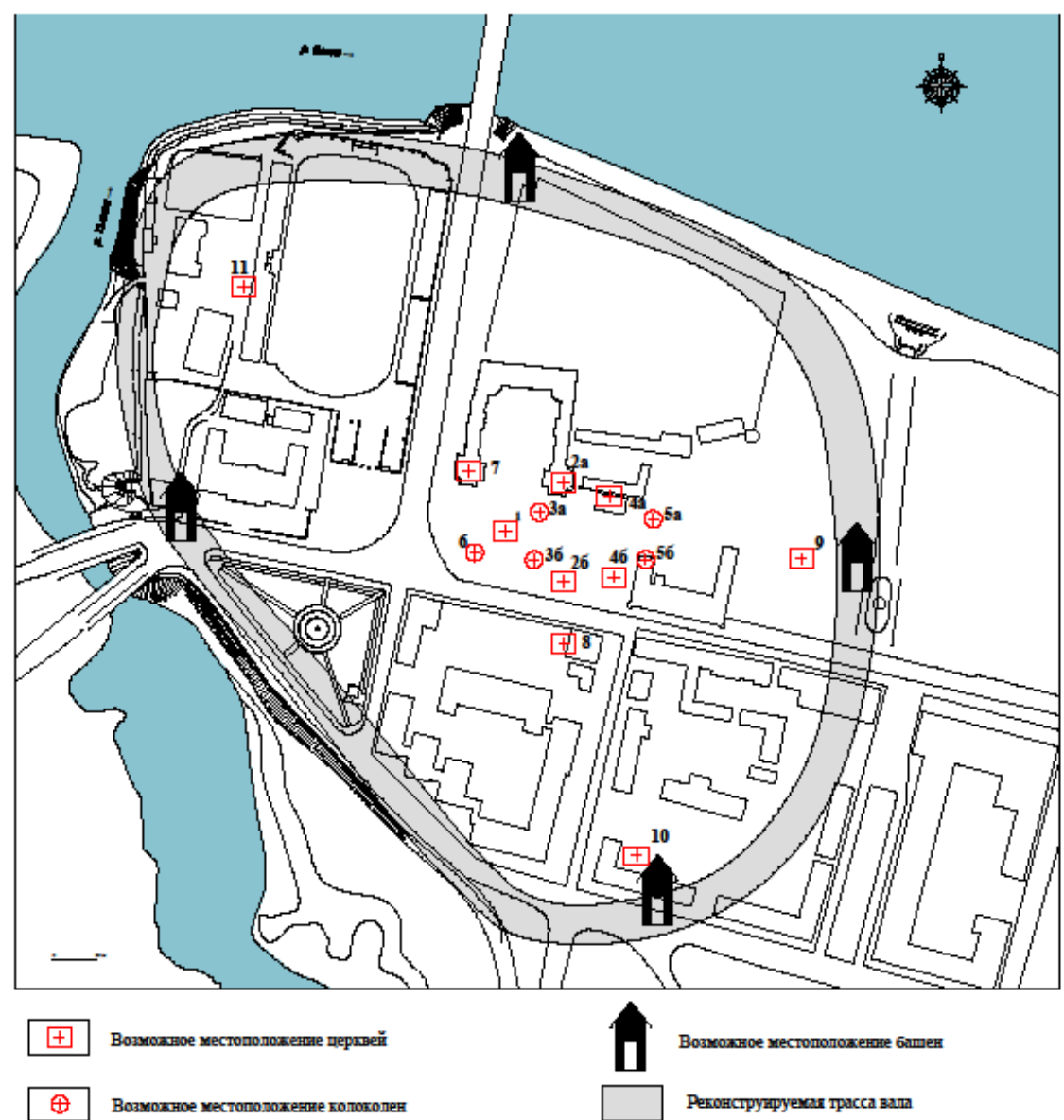

Fig. 1. Scheme of the location of the churches of the Tver Kremlin which could be built by the end of the 13th century.

a. 1 - the Church of Kozma and Demjan; 2a - the Cathedral of Our Saviour Transfiguration; 26 - the Cathedral of Our Saviour Transfiguration; $3 a$ - bell-tower of the Cathedral of Our Saviour Transfiguration; 36 - bell-tower of the Cathedral of Our Saviour Transfiguration; 4 a - the Cathedral of St. Athanasius Monastery; 46 - the Cathedral of St. Athanasius Monastery; $5 a$ - bell-towe of St. Athanasius Monastery; 56 - bell-tower of St. Athanasius Monastery; 6 - bell-tower of the Church of Kozma and Demjan; 7 - house temple in the Bishop's Yard; 8 -the Church of
ons Archangel Mikhail in the Prince's Yard; 9 - the Church near Vladimirskie gate; 10 - the Church of St. Vasiliy (?); 11 - the Temple of St. Nikola. 


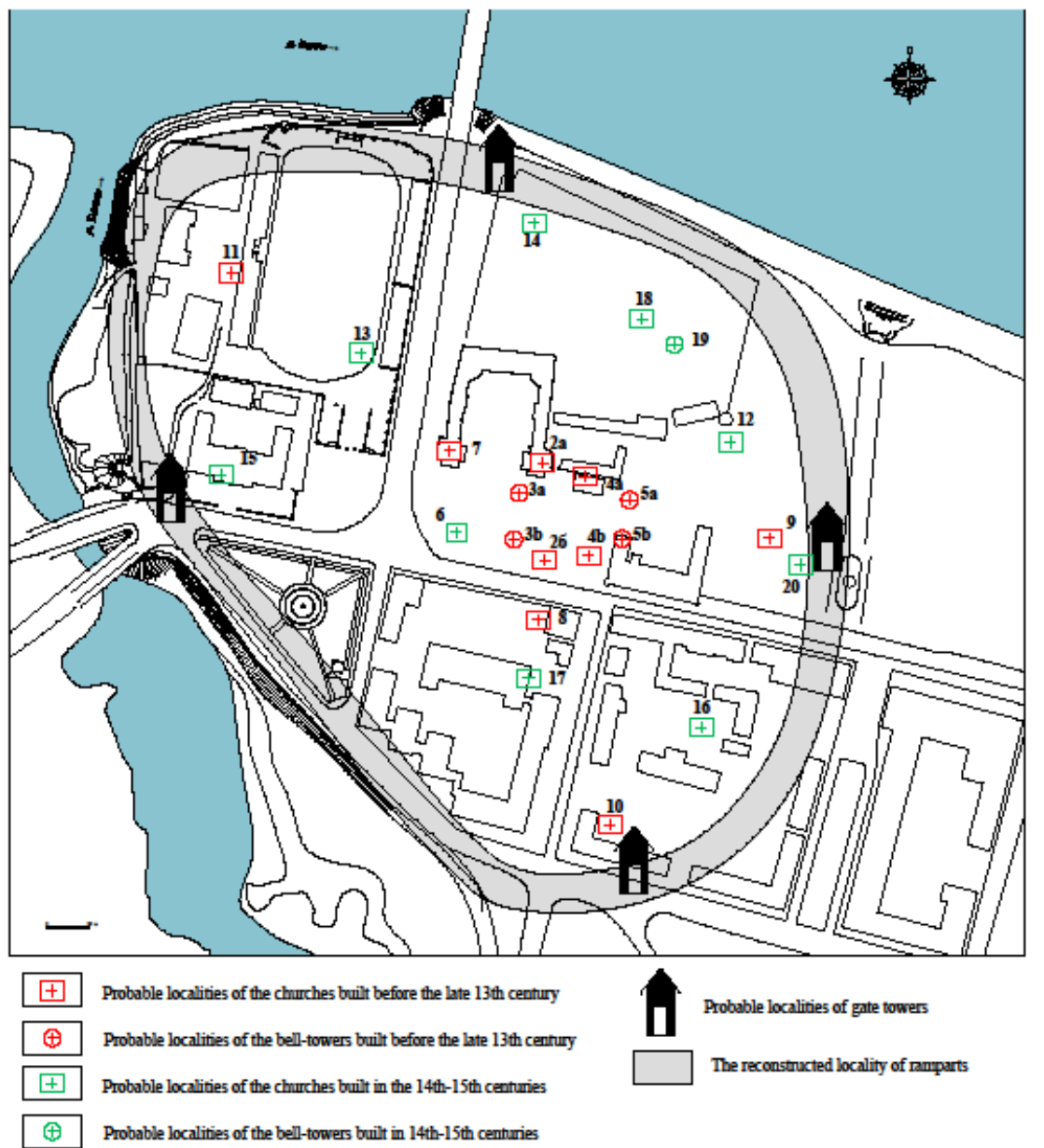

Fig. 2. Scheme of the location of the churches of the Tver Kremlin which could be built in the 14th -15 th centuries.
2a - the Cathedral of Our Saviour Transfiguration; $2 \sigma$ - the Cathedral of Our Saviour Transfiguration; 3a - bell-tower of the Cathedral of Our Saviour Transfiguration; 36 - bell-tower of the Cathedral of Our Saviour Transfiguration; $4 \mathrm{a}$ - the Cathedral of St. Athanasius Monastery; 46 - the Cathedral of St. Athanasius Monastery; 5a - bell-tower of St. Athanasius Monastery; 56 - bell-tower of St. Athanasius Monastery; 6 - house temple in the Bishop's residence (15th century); 7 - house temple in the Bishop's Yard (the Church of John the Monastery; 56 - bell-tow 15 ( St. Athanasius Mo" Merciful since the early 15th century), 8 - palace" che of Archangel Mikhil in the Prince's Yard, 9 - church near Vladimirskie gate, 10 - the Church of St. Vasiliy (?); 11 - the Temple of St. Nikola; 12 - the Church of the Holy Virgin Nativity (?); 13 - the Church of St. George (?); 14 - church near Volzhskie gate; 15 - church near Tmatskie gate; 16 - church in
the yards of the south-eastern part of the Kremlin; 17 - the Boris and Gleb Temple of 1435-1438; 18 - the Cathedral of the Trinity Monastery; 19 - bell-tower of the Trinity Monastery;

It may well be that the Church of St. Mikhail appeared in the Prince's Yard in the second half - the late 13th century also. We suppose that the temple mentioned in 1399 was its successor (the same consecration and territory). It was in "the house Church of St. Mikhail", where a miraculous icon presented by the Patriarch was placed [13]. This construction can be connected with a grandson of Mikhail Yaroslavich Tverskoy - the Prince Mikhail Aleksandrovich, but we should take into account that Mikhail Yaroslavich was ready to connect important events of his life and the destiny of the principality with Archistratigus Mikhail [13]. ${ }^{1}$ We cannot exclude that the earliest Temple of Archistratigus Mikhail could appear in the Prince's

\footnotetext{
1 "On the Cathedral of Archistratigus Mikhail" i.e. on the 8th of November the Transfiguration Cathedral was consecrated (1290) and the wedding of the prince with Rostov Princess Anna Dmitrievna took place (1294): [13].
}

Yard in the second half - the last quarter of the 13th century. Evidently, that church was a separate building and was integrated with the constructions of the Prince's Yard, but in the 14th century, it could be included in the complex as a "house church" (it could be rebuilt) ("Fig. 1", "Fig. 2").

This church could be wooden in the 13th - 14th centuries and could be rebuilt in stone in the middle of the 15 th century $[13,19]$. The conclusion on the probability of the existence of the St. Mikhail Church in the second half - the late 13th century can be confirmed by the results of archaeological excavations carried out in the territory of the Prince's Yard. In 2013, the disturbed remains of human beings from a nearby cemetery were revealed there; the cemetery appeared beside the unknown church no later than in the 13th century. In their turn, some finds made there underline 
a high social position of the people, who lived in the area of the Prince's Yard [20].

In addition to the above-mentioned churches, a house temple had to be in the structure of the Bishop's Yard, which was evidently placed in the Tver Kremlin in the second half of the 13th century, after the Tver Episcopate had been created. We admit that at the early stage a small monastery could have already appeared in the complex of the Bishop's residence. At least the source of the middle 16th century evidences that there was the Trinity Monastery; however, the author of the document underlines that the monastery was placed "behind the Bishop's Yard" [11] that is why the Monastery of St. Athanasius could fulfil the function of the Bishop's monastery at the early stage of the Bishop's residence.

Finally, some presumably wooden churches were erected in other parts of the Kremlin in the second half - the late 13th century. They could be erected near the gates as well as among the inhabitants' yards, for example, beside the yards of noble citizens serving under the grand princes of Tver.

The suggestion of numerous cult constructions located in the territory of the Tver Kremlin by the early 14 th century is indirectly confirmed by the information about the fire of 1318. During this catastrophe "the large part of the city and 6 churches were burnt down" [13]. Evidently, most of the churches were wooden. The stone one was the Transfiguration cathedral and, presumably, the bell-tower built nearby. We admit that a stone aisle temple was built beside the Tver Cathedral in the late 13th - the early 14th century; another one could be constructed no later than the first third of the 14th century. As a result, a volume-space composition containing the "small" Churches of the Presentation and of St. Dmitry besides the Cathedral of Transfiguration appeared there [3].

It is evident that the events of 1327 , when the Tver prince had to escape to Pskov, and the following devastation of Tver [21] stopped the development of church building for decades. However, unlike the building of stone churches, which stopped for a long time, wooden churches continued to be built, apparently because of fires and destructions.

Archaeological excavations of 2014-2015 confirmed the existence of a wooden church in the south part of the Kremlin since the beginning of the 14th century. The excavations revealed a part of a medieval cemetery [22]. The authors of the study support A.S. Schenkov, who supposed that the Church of Annunciation of the Holy Virgin had been located there [23], as well as N.V. Zhilina, who suggested that the first temple there had been the Church of St. Vasiliy [24] ("Fig. 1", "Fig. 2").
There are no doubts in the location of the church suggested by A.S. Schenkov, because it was placed there, near the Annunciation (south) gate, according to the city plan of 1710s [17]. Probably the same construction at the same place was depicted in the icon of 1660s [3]. The documents of the middle of the 16th century confirm the existence of the Annunciation Church in the city of Tver [11], while the Cadastre book of 1626 records it as a wooden construction [15].

The Church of St. Vasiliy is mentioned in chronicle once, in 1391, located near the gate: it "completed the gate near St. Vasiliy" [13]. It is no coincidence that the annalist marks the Church of St. Vasiliy as a landmark to define the location of the gate. Possibly this gate had no name in contrast to the mentioned in the same source Volzhskie (north) and Tmatskie (west) gates. Knowing the location of these gates, it seems logical to suggest that the Annunciation gate, mentioned in cadastre books of the 16th century and placed on the plan of the early 18th century, was at some point the gate near the Church of St. Vasiliy (fig. 2). Now the remains of this temple are possibly laid around the hotel "Centralnaya". We cannot exclude the variant of another location of this church. It could stand near Vladimirskie (east) gate connecting the Kremlin with Zagorodsky posad of Tver. Nevertheless, the presence of the cemetery of no later than the early 14th century near this construction supports our conclusion that cult buildings could be standing near the city gates as far back as the late 13th century. ("Fig. 2").

Presumably, in the 14th century there existed a church the destructed cemetery remains of which were found in the course of archaeological excavations in the southeast part of the "Khimik" stadium [20]. Now this church cannot be localized exactly, that is why we can tentatively suggest that it could be the wooden Church of St. George the Martyr, taking into account its relative closeness to the Bishop's Yard. In the middle of 1620s, this church stood "near the Archbishop's Yard" [15]. The temple mentioned in the source of the 17th century could be a successor of the building standing there in the 14 th century.

It should be noted that not far from the Church of St. George, the Cadastre book of 1626 documented a wooden Temple of St. Nikola the Miracle-Worker [15], which in the second half of the 17th century was replaced by a stone one [25]. Possibly, it existed in the 14 th century as the above mentioned unknown church, because it took one of the key positions of the Tver Kremlin providing the space and compositional connection with the town which formed the accents of Zavolzhye and Zatmachye territories ("Fig. 2").

The end of the 14th - the first quarter of the 15 th centuries was the period of the rise of the Tver Principality. This situation redounded upon the church building by secular and spiritual powers in the most 
significant place of the capital of the Upper Volga, in the Kremlin. The additional stimulus for this activity was the fire of 1413, when "the city of Tver was burnt down, the whole city, the wall, and 20 churches were burnt" [13]. However, the reconstruction of the cathedral in 1399 gave rise to large works to renew the Tver Kremlin [10]. Short time later, in 1407, a new bell-tower was built, probably in stone. It was placed near "the old one", which possibly preserved it for a time ("Fig. 2").

The fire stimulated the renovation of the main Kremlin residencies: the Prince's one and the Bishop's one. We can only imagine what was done in the Prince's Yard, but in the Bishop's one a centrical four or eight petalled temple of John the Merciful was built, typologically close to some constructions of western Russian cities of the 13th-14th centuries [2]. As a result, the cathedral ensemble comprising some stone constructions appeared in the centre of the Kremlin by the end of Ivan Mikhailovich's ruling (1399-1425). The Tver Prince Boris Aleksandrovich continued the works of Ivan Mikhailovich and evidently totally reconstructed the Prince's residence in 1430s - 1450s. The new Temple of St. Mikhail (1452-1455) as well as the Church of St. Boris and Gleb (1435-1438) appeared there [13]. Both of the churches were placed in "seni" (the ground floor of a palace) [11], so we can suggest that the stone palace complex had been constructed in the territory of the Prince's Yard by the middle of the 15 th century. The temples erected in the second quarter - the middle of the 15th century became a part of it. Possibly, at the same time a stone palace was built near the Church of John the Merciful in the Bishop's Yard, which could become a house temple of the Bishop.

Implementing a town planning programme, Boris Aleksandrovich placed the Church of the Entry of Christ into Jerusalem "on the gate of the city of Tver kept by the power of God" [19]. Evidently, it was the main gate of the Tver Kremlin - the Vladimirskie one ("Fig. 2"). The gate temple was made of wood, as were the walls and towers of the Kremlin.

We admit that the building of new churches and the reconstruction of the existed ones was made in the time of the last Tver Prince Mikhail Borisovitch, but the sources do not document these events as well as archaeology has not revealed the constructions of the last period of the Tver Principality independence.

\section{CONCLUSION}

To summarize the study, we can likely state that some decades after the creation of the Tver Principality, by the end of the 13th century numerous temples had been built in the Tver Kremlin. At that time, the only stone construction was the Cathedral of Transfiguration. The 14th century did not substantially change the correlation between the stone and wooden constructions either, though two stone aisles to the cathedral were erected.

The 15 th century became a turning point due to the rise of the mightiness of the principality. Taking into account the evidence of the source about 20 documented burnt temples in 1413 , we can likely state that there had been no less than 20 churches in the territory of the Tver Kremlin by the 1480s though among them there could be aisle churches. The most significant complexes with dominating stone constructions were in the centre of the Kremlin. The ensemble of the Transfiguration Cathedral was in the focus of the Kremlin. To its south, there was the Prince's Yard, the decoration of which was two stone temples. To its north, there stood the Bishop's residence with the original in its architecture Church of John the Merciful. It was connected with the Bishop's palace and became the stone construction in the middle - the second half of the 15 th century. The rest of the churches of the Tver Kremlin, including the monastery ones, were evidently made of wood at the fall of the independence of Tver.

\section{References}

[1] A.M. Salimov, The Bishop's Yard in the Tver Kremlin at the End of the 17th - the 18th Centuries: Locality, Borders, Character of building (Arkhiyereyskiy dvor v Tverskom kremle na rubezhe XVII-XVIII vekov: mestopolozheniye, granitsy, kharakter zastroyki) in Architectural Heritage, issue 49, pp. 106126, 2008 [in Russian]

[2] A.M. Salimov, The Medieval Architecture of Tver and Neighboring Territories. The 12th - the 16th centuries (Srednevekovoye zodchestvo Tveri i prilezhashchikh zemel. XII - XVI veka), vol. I, pp. 74-148, 153, 225-258, 379, 391 [in Russian]

[3] A.M. Salimov, The Tver Cathedral of Our Saviour Transfiguration. 13th -16 th centuries (Tverskoy SpasoPreobrazhenskiy sobor. XIII - nachalo XXI veka). Tver, 2019, pp. 44-47, 103, 255-273 [in Russian].

[4] Complete Collection of Russian Chronicles, vol. 10. SaintPetersburg, 1885, pp. 150, 153, 171 [in Russian].

[5] K. Cheredeev, Biographies of Tver Bishops (Biografii tverskikh iyerakhov). Tver, 1859 , p. 6 [in Russian].

[6] G.V. Popov, Icon Painting (Ikonopis) in Painting and Decorative Arts of Tver 14th-16th Centuries (Zhivopis prikladnoye iskusstvo Tveri. XIV-XVI veka). Moscow, 1979, p. 19. [in Russian].

[7] L.A. Belyaev, I.A. Safarova and A.N. Khokhlov, The Cathedral of Our Saviour Transfiguraion in the Tver Kremlin: the Results of Excavations of 2012-2014 ( Spaso-Preobrazhenskiy sobor v Tverskom kremle: itogi raskopok 2012-2014 gg) in Russian Archaeology, vol. 2, 2018, p. 148. [in Russian].

[8] Complete Collection of Russian Chronicles. Vol. I, Leningrad, 1927, pp. 482-483. (PSRL. T. 1. L. 1927. Stb. 482-483). [in Russian]

[9] Complete Collection of Russian Chronicles. Vol. XVIII, SaintPetesburg, 1913, p. 81. (PSRL. T. 18. SPb. 1913. S. 81). [in Russian].

[10] Complete Collection of Russian Chronicles. Vol. XI, Moscow, 1965, pp. 3, 198 [in Russian] 
[11] Cadastre Materials of the Tver Uezd of the 16th Century (Pistsovyye materialy Tverskogo uyezda XVI veka), ed by A.V. Antonov. Moscow, 2005, p. 163, 164, 184, 229, 273, 295, 296 [in Russian].

[12] Extract from the Cadastre Books of Writing and Measure of Fedor Ignatyev and Podyachiy Timofey Stefanov of 1627-28 (Vypis iz tverskikh pistsovykh knig pisma i mery Fedora Ignatyeva da podyachego Timofeya Stefanova 1627-28 gg.). Tver, 1916. Vol. 1, p. 36 [in Russian].

[13] Complete Collection of Russian Chronicles. Rogozhskyi Chronicle (PSRL. Rogozhskiy letopisets), vol. XV. Petrograd, 1922, pp. 33, 171, 174, 406, 445, 486, 490-491, 495. [in Russian].

[14] V.N. Storozhev, Checking Book of Tver of 1616 (Dozornaya kniga Tveri 1616 goda). Tver, 1890, p. 13 [in Russian].

[15] Extract from the Cadastre Books of Potap Narbekov and Podyachiy Bogdan Fadeev. 1626. (Vypis iz Tverskikh pistsovykh knig Potapa Narbekova i podyachago Bogdana Fadeyeva. 1626 god). Tver, 1901, pp. 13, 17, 23, 27 [in Russian].

[16] Russian State Archive of Ancient Acts. F. 237, op. 1, f. 46, 1701-1702, 1. 94 b. (RGADA. F. 237. Op. 1. D. 46. 1701-1702 gg. L. 94 ob.) [in Russian].

[17] Russian State Military Historical Archive. F. 349, op. 39, f. 724. Painted plan of Tver of 1710-es. (RGVIA. F. 349. Op. 39. D. 724. Risovannyy plan Tveri 1710-kh gg.) [in Russian].

[18] N.N.Voronin, Architecture of North-Eastern Rus' of the 12th the 15th centuries (Zodchestvo Severo-Vostochnoy Rusi XII XV vekov). Moscow, 1962, vol. 2, p. 144. [in Russian].

[19] The Word Commendable by Foma the Monc (Inoka Fomy Slovo pokhvalnoye) in Monuments of Literature of Ancient Rus'. The Second Half of the 15th century (Pamyatniki literatury drevney Rusi. Vtoraya polovina XV veka). Moscow, 1982, pp. 268, 269, 328-329 [in Russian].

[20] E.A. Romanova, Report about the Protective Archaeological Excavations During the Works on Communications to the Emperor's Travel Palace in the Territory of the Former Kremlin in Tver in 2013. Archive of Institute of Archaeology. R-1. 49871-49875. (Romanova E.A. Otchet ob okhrannykh arkheologicheskikh issledovaniyakh pri prokladke kommunikatsiy $\mathrm{k}$ Imperatorskomu putevomu dvortsu na territorii b. Kremlya v g. Tveri v 2013 g. Arkhiv IA RAN. R-I. № 49871-49875). [in Russian].

[21] V.S. Borzakovskyi, The History of Tver Principality (Istoriya Tverskogo knyazhestva). Tver, 1994, pp. 124-128. [in Russian].

[22] A.N. Khokhlov, S.A. Kungurtseva and A.B. Ivanova, To the Study of Medieval Necropolis near the Church of Annunciation of the Holy Virgin in the South Part of the Tver Kremlin (K izucheniyu srednevekovogo nekropolya u tserkvi Blagoveshcheniya Presvyatoy Bogoroditsy v yuzhnoy chasti Tverskogo kremlya) in Tver, Tver Land and Nearby Territories in the Epoch of the Middle Ages (Tver, tverskaya zemlya i sopredelnyye territorii v epokhu srednevekovia), vol. 12, Tver, 2019, p. 221 [in Russian].

[23] A.S. Schenkov, An Attempt of Reconstruction of Tver of the End of the 17th Century (Opyt rekonstruktsii plana Tveri kontsa XVII v.) in Architectural Heritage, vol. 28. Moscow, 1980, p. 30 [in Russian].

[24] N.V. Zhilina, The Topography of Churches of Ancient Tver According to Written Sources and in Connection with Archaeological Data in Tver, Tver Land and Nearby Territories in the Epoch of the Middle Ages (Topografiya khramov drevney Tveri po pismennym istochnikam $\mathrm{i} v$ svyazi $\mathrm{s}$ dannymi arkheologii) in Tver, tverskaya zemlya i sopredelnyye territorii v epokhu srednevekovia, vol. 1. Tver, 1996, p.69. [in Russian].

[25] A.M. Salimov, The Church of St. Nikola in Kapustniki and the Tver Architecture of the second half - the end of the 17th
Century (Tserkov Nikoly v Kapustnikakh i tverskoye zodchestvo vtoroy poloviny - kontsa XVII veka) in Arkhitekturnoye nasledstvo, vol. 70. Saint-Petersburg: Kolo, 2019, pp. 32-41 [in Russian]. 